\title{
Reflections on Liszt
}


ALSO BY ALAN WALKER

A Study in Musical Analysis

An Anatomy of Musical Criticism

Franz Liszt: Volume One, The Virtuoso Years, 1811-1847

Franz Liszt: Volume Two, The Weimar Years, 1848-1861

Franz Liszt: Volume Three, The Final Years, 1861-1886

The Death of Franz Liszt Based on the Unpublished Diary of His Pupil

Lina Schmalhausen

\section{EDITOR OF}

Frédéric Chopin: Profiles of the Man and the Musician

Franz Liszt: The Man and His Music

Robert Schumann:The Man and His Music

Living with Liszt: From the Diary of Carl Lachmund, an American Pupil of Liszt, 1882-1884

Liszt, Carolyne, and the Vatican: The Story of a Thwarted Marriage, as It Emerges from the Original Church Documents (With Gabriele Erasmi) 


\section{Alan Walker}

Reflections on Liszt 
Copyright (C) 2005 by Alan Walker

All rights reserved. Except for brief quotations in a review, this book, or parts thereof, must not be reproduced in any form without permission in writing from the publisher. For information, address Cornell University Press, Sage House, 5 I 2 East State Street, Ithaca, New York I 4850.

First published 2005 by Cornell University Press

Printed in the United States of America

Library of Congress Cataloging-in-Publication Data

Walker, Alan, I930-

Reflections on Liszt / Alan Walker. p. cm.

Includes bibliographical references (p. ) and index.

ISBN o-80I4-4363-6 (cloth : alk. paper)

I. Liszt, Franz, I8 I I-I886-Criticism and interpretation. 2. Music- I9th century-History and criticism. I. Title.

ML4Io.L7W296 2005

$78 \mathrm{o}^{\prime} .92-\mathrm{dc} 22$ 2004030467

Cornell University Press strives to use environmentally responsible suppliers and materials to the fullest extent possible in the publishing of its books.

Such materials include vegetable-based, low-VOC inks and acid-free papers that are recycled, totally chlorine-free, or partly composed of nonwood fibers. For further information, visit our website at www.cornellpress.cornell.edu.

Cloth printing IO $9 \begin{array}{llllllll}8 & 7 & 6 & 5 & 4 & 3 & 2 & \text { I }\end{array}$ 


\section{For Valerie Tryon,}

whose peerless interpretations of the music of Franz Liszt

bave spoiled many another pianist for me 
